\title{
Uvidenhedens Tåge
}

\author{
Her begynder en bog om kontemplation, som kaldes \\ Uvidenhedens Tåge \\ I hvilken en sjæl bliver forenet med Gudr
}

\section{Her begynder Prologen}

I Faderens, og Sønnens og Helligåndens navn.

Jeg beder dig indtrængende, med al den styrke og laraft som Guds kærlighed giver mig, at du (hvad enten denne bog er din ejendom, om du har den til låns, eller blot skal overbringe den til en anden) af egen fri vilje, hverken vil citere fra eller blot nævne denne bog for nogen, medmindre personen, efter dit bedste skøn, er fuldt og helt besluttet på at efterfølge Kristi eksempel til perfektion. Med det mener jeg at følge Kristus, ikke bare i det aktive og verdslige liv, men i det allerhøjeste kontemplative liv, som det er muligt for en perfekt sjæl $i$ en jordisk krop at opnå gennem Guds nåde.

Og denne person skal, efter din vurdering, gøre alt, hvad der står i hans magt (og $i$ lang tid forinden have gjort alt, hvad der står $i$ hans magt), for at nå frem til det kontemplative liv gennem et dydigt aktivt liv. Hvis dette ikke er tilfældet, vil denne bog ikke være egnet for ham. Ydermere, hvis nogen vil læse denne bog, kopiere den eller læse højt fra den (eller bevirke at den bliver læst, kopieret eller læst højt fra), så beder jeg dig indtrængende om, at du så făr ham til at bruge tid på denne bog. For der kunne være et sted, måske $i$ begyndelsen eller i midten af bogen, som er uklart, og hvor meningen ikke fremgår umiddelbart af sammenhængen. Et sådant sted kunne jo blive forklaret bagefter eller måske hen mod slutningen. Det er meget let at blive vildledt, hvis man kun læser enkelte dele af bogen og forbigår andre. Derfor, for at undgå sådanne vildfarelser, er det yderst vigtigt, at både du og andre gør, som jeg siger.

Det bekymrer mig ikke det mindste, at diverse sludrechatoller, pedanter, rygte- og rænkesmede, eller brovtende og selvrosende narrehoveder aldrig ser denne bog. Den har aldrig været tiltænkt dem, og de gør klogest $\mathrm{i}$ at holde sig væk. Det gør også alle de højstuderede røvere og dem uden lærdom, som blot er styret af nysgerrighed. Det er meget muligt, at de lever et aktivt liv i dyd, men alt dette er ikke passende for dem.

Derimod er denne bog passende for dem, som, om end de lever et aktivt liv i verden, er kaldet (gennem Guds vilje, som er uransagelig) til et liv, som ofte tager del i den højeste kontemplative bevidsthed. Skulle sådanne personer se denne bog, er jeg sikker på, at de ved Guds nåde vil finde megen trøst og vejledning heri. 
Bogen er inddelt i femoghalvfjerds kapitler. Af disse kapitler forklarer det sidste, hvordan en sjæl kan fastslå, om Gud kalder den til dette arbejde eller ej.

Kapitel 3

Opløft dit hjerte til Gud med yd'myg kærlighed: og tænk på Gud selv, og ikke på noget af hans værk. Ja, føl sågar lede ved at tænke på andet end Gud selv, således at intet andet vil forekomme $i$ din bevidsthed og i din vilje end blot ham selv. Og dette indebærer, at man skal glemme alt Guds skaberværk og dettes betydning, så dine tanker og tilbøjeligheder ikke er rettet mod alt dette, hverken generelt eller specifikt. Slip det og vær ikke opmærksom på det. [...]

Giv aldrig op, men arbejd hårdt til du har denne længsel efter Gud selv. I begyndelsen vil du kun møde mørke og en tåge af uvidenhed. Du ved ikke, hvad betydningen af det er; du ved blot, at du føler en bar længsel i din vilje efter Gud.

Uanset hvad du foretager dig, vil dette mørke og denne tåge stå mellem dig og din Gud, og bevirke at du ikke kan se ham klart i din fornufts lys eller erfare hans kærlighed $\mathrm{i}$ dine følelser.

Bered dig på at skulle vente $\mathrm{i}$ dette mørke så længe, det er nødvendigt, men fortsæt med at længes efter ham, du elsker. For hvis du skal se ham eller føle ham $\mathrm{i}$ dette liv, må det altid være igennem denne tåge og i dette mørke. Hvis du vil arbejde hårdt, som jeg beslriver det her, så er jeg overbevist om, at du ved Guds vilje vil opnå, hvad du ønsker.

\section{Kapitel 4}

For at du ikke skal tage fejl eller fare vild, vil jeg prøve at forklare det lidt nærmere.

Det tager ikke lang tid at bringe dette værk til ende. Nej, faktisk er det det korteste værk, man kan forestille sig. Det tager hverken kortere eller længere tid end et athomus. Et athomus er, som en filosof udi astronomiens videnskab kan fortælle dig, den mindste inddeling af tid. Det er så småt, at det, på grund af sin størrelse, er udeleligt og så godt som ufatteligt. Det er det, der tænkes på, når der siges, at "du skal forklare, hvorledes du har anvendt al den tid, der er dig givet". Det er kun passende, at du skal forklare det; for det er hverken kortere eller længere end en enkelt impuls, som produceres $\mathrm{i}$ din vilje. Og det er viljen, som udgør den vigtigste kraft i din sjæl. [...]

\section{Kapitel 5}

Hvis du nogensinde når frem til denne tåge og lever og arbejder i den, sådan som jeg forklarer det, så skal du, ligesom denne tåge står over dig og mellem dig og din Gud, anbringe en tåge af glemsel under dig, og mellem dig og alt det skabte. Det er let for dig at tro, at du er så langt fra Gud på grund af denne uvidenhedens tåge, som står mellem 
dig og Gud. Men det ville være korrekt at sige, at du er langt fjernere fra ham, hvis der ikke står en tåge af glemsel mellem dig og alle de skabninger, der nogensinde er skabt. Når jeg siger alle de skabninger, som nogensinde er skabt, så tænker jeg ikke bare på disse skabninger, men også på disses handlinger og de betingelser, de er til på. Og det uanset om du tænker på disse skabninger som værende af fysisk eller åndelig natur.

Selvom det til tider er nyttigt at have bestemte skabninger og disses handlinger og betingelser $i$ tankerne, så er det dog nytteløst $i$ denne sammenhæng. For det at huske på, hvad en ting er eller gør, har en åndelig effekt. Din sjæls øje fokuseres der på, ligesom en bueskyttes øje fæstnes på det mål, han skyder mod. Dette kan jeg sige dig: alt, hvad du tænker på, står uden for dig, og mellem dig og Gud. Og du står så meget fjernere fra Gud, jo flere ting du tænker på, som ikke er Gud.

Faktisk, sagt i al respekt, så er det ikke til megen nytte i dette værk at tænke på Guds kærlighed, ej heller på jomfruen, eller de engle og helgener, som er i bimlen, og heller ikke på bimlens herligheder. Du vil måske forsøge at give føde og styrke til din længsel gennem et skarpt fokus pả sădanne ting, men i dette tilfælde og $\mathrm{i}$ dette værk er det dog til ingen nytte. For selvom det er godt at tænke på Guds kærlighed og at elske og prise ham for den, så er det dog langt bedre at tænke på ham $i$ hans blotte væren og at elske og prise ham i ham selv.

På dansk ved Allan Fogh Westphall

Note

r. I udarbejdelsen af denne oversættelse har jeg anvendt følgende tekstudgaver: Evelyn Underhill (red.): The Cloud of Unknowing, London: J.M. Watkins, I9I2; Phyllis Hodgson (red.): The Cloud of Unknowing and The Book of Privy Counselling, Early English Text Society, Original Series 218, London: Oxford University Press, r944; Clifton Wolters (red.): The Cloud of Unknowing and Other Works, Harmondsworth: Penguin Books Ltd., r961; A.C. Spearing (red.): The Cloud of Unknowing and Other Works, Harmondsworth: Penguin Books Ltd., 20or.

En stor tak skal gå til lektor Bodil Sørensen for forslag og rettelser i forbindelse med oversættelsen. 